\title{
ПСИХОЛОГИЧЕСКИЕ ОСОБЕННОСТИ ЛИЧНОСТИ ВОЕННОСЛУЖАЩЕГО СРОЧНОЙ СЛУЖБЫ С РАЗЛИЧНЫМ ТИПОМ ОТНОШЕНИЯ К СЛУЖБЕ В АРМИИ
}

\section{PSYCHOLOGICAL FEATURES \\ OF THE PERSONAL SERVICE URGENT SERVICE WITH DIFFERENT TYPES OF ATTITUDE TO SERVICE IN THE ARMY}

A. Fedorov

Summary: The article examines the features of military professional activity and the psychological characteristics of conscripts, which influence the formation of the type of attitude towards service in the army. The authors give the main directions of socio-psychological conditions that contribute to a decrease in the level of negative perception of young people doing military service in a military unit. A favorable sociopsychological climate in the military collective is required.

Keywords: soldier, individual psychological properties, personality, warrior, abilities, individual orientation, activity.
$\mathrm{H}$ а сегодняшний день армия находится на этапе активного реформирования. Ослабла социальная защищенность военнослужащих. Следствием этого стало снижение безопасности России. Это определяет актуальность темы. Важное место в комплексе индивидуально-психологических свойств личности воина занимают его способности, выражающие готовность военнослужащего к овладению определенными видами деятельности с заданной эффективностью. Каждый военнослужащий обладает способностями, присущими только ему. Поэтому психолог должен быть заинтересован в их своевременном выявлении и внимательном изучении.

Оценка способностей солдат, проходящих срочную службу, должна быть целеустремленной и систематической. При этом главное максимально гармонично согласовать возможности и способности воинов с требованиями конкретных военных специальностей [6, с. 34].

По мнению А.Г. Маклакова, необходимо увидеть своеобразие индивидуальной направленности воина, правильно оценить ее и верно прогнозировать его последующие поступки и действия [3, с. 405].

В типологии твердо установлено положение, что все психические процессы и психические состояния могут быть изучены только в конкретной деятельности чело-
Фёдоров Александр Фёдорович

К.nсх.н., дочент, с.н.с., ФКУ НИИ ФСИН России, г. Москва; Владимирский государственный университет имени Александра Григорьевича и Николая Григорьевича Столетовых zimbur79@mail.ru

Аннотация: В статье рассматриваются особенности военно-профессиональной деятельности и психологические особенности солдат срочной службы, которые влияют на формирование типа отношений к службе в армии. Авторы дают основные направления социально-психологических условий, способствующих снижению уровня негативного восприятия молодыми людьми, проходящих срочную службу в воинской части. Необходим благоприятный социально-психологический климат в воинском коллективе.

Ключевые слова: военнослужащий, индивидуально-психологические свойства, личность, воин, способности, индивидуальная направленность, деятельность.

века [5, с.378].

Побудительными причинами человеческой деятельности являются мотивы. Мотивы - это совокупность внутренних и внешних условий, которые вызываю активность.

Цель и задачи могут совпадать (задача позволяет достичь искомой цели), но в сложных видах деятельности задача обычно способствует достижению частной цели на пути к главной. И только после этого он может претендовать на то, чтобы называться специалистом.

Еще один вид деятельности - обучение. Обучение может быть организованным и осуществляться в специальных образовательных учреждениях. Обучение взрослых может происходить путем самообразования.

Основной характеристикой любой трудовой деятельности служит степень ее социальной значимости, и с этой точки зрения военно-профессиональная деятельность по праву считается одной из наиболее важных [1, c. 92].

Необходимо рассмотреть особенности военно-профессиональной деятельности, которая является сложной и многообразной. 
Особую роль в организации деятельности играют: воля, мышление, внимание, восприятие и другие психические процессы.

Однако деятельность - это не только психическая сфера, но и физиология, где центральное место занимает физиология движения. Кроме этого, деятельность непосредственно связана с социальной сферой, поскольку становление человека как представителя человеческого общества осуществляется в процессе его сознательной деятельности. Рассмотрим структуру и основные компоненты деятельности современного человека.

В отечественной психологии исследование структуры человеческой деятельности осуществляется с позиции теории деятельности [4, с. 256].

Проблемой исследования является то, что психологические особенности солдат срочной службы влияют на формирование типа отношений к службе в армии.

Цель исследования - изучение психологических особенностей солдат срочной службы с различным типом отношения к службе в армии.

Объектом данной работы являются - солдаты срочной службы.

Предметом - психологические особенности солдат срочной службы с различным типом отношения к службе в армии.

Гипотеза данного исследования - можно предположить, что существуют различия в психологических особенностях солдат срочной службы с различным типом отношения к службе в армии.

С.Л. Рубинштейн, приступая к характеристике личности, особое внимание обращает, на зависимость психических процессов от личности [2, с. 60].

Теоретическую базу исследования составили: Личностно-деятельностный подход Леонтьева А.Н. и Концепции формирования личности и ее деятельности в условиях военной службы.

Эмпирическая база исследования: на базе воинской части г. Владимира. В исследовании участвовали солдаты, проходящие срочную службу в воинской части, в количестве 60 человек. Методы исследования: практические (тестирование), теоретические (анализ литературы), математические (коэффициент корреляции Спирмена).

На первом этапе проводился анализ методической литературы по теме исследования и ознакомление с ра- ботой программы «Psychometric Expert».

На втором этапе проходила выборка и разделение на три группы в зависимости от типа отношения к службе в армии.

На третьем этапе, на основании полученных результатов тестирования и беседы составлялись психологические портреты представителей выделенных подгрупп.

Исследование проводилось на военнослужащих в возрасте от 18 до 23 лет, проходящих срочную службу в воинской части. Численность выборки - 60 человек. 15\% испытуемых имеют среднее (полное) общее образование; 40\% - среднее профессиональное образование; и 45\% испытуемых имеют высшее образование.

С помощью опросника «Установки на военную службу» разделили исследуемых на три группы: военнослужащие по призыву с отрицательным, нейтральным и положительным типом отношения к службе в армии. А именно, в процентном соотношении получили следующие результаты:

47,5\% - солдаты срочной службы, которые относятся к службе в армии отрицательно, 25\% исследуемых относятся к службе в армии положительно и 27,5\% военнослужащих по призыву придерживаются нейтральной позиции в отношении службы в армии. Для выявления уровня личностной и ситуативной тревожности у солдат срочной службы использовали методику Ч.Д. Спилберга - Ю.Л. Ханина.

Испытуемые с низким уровнем личностной тревожности, как правило, характеризующаяся депрессивным, неактивным состоянием, с низким уровнем мотиваций, составляют $30 \%$, из которых по 50\% представлены испытуемые с нейтральным и положительным типами отношения к службе в армии. Личности, относимые к категории высоко-тревожных склонны воспринимать угрозу своей самооценке и жизнедеятельности в обширном диапазоне ситуаций и реагировать на них выраженным состоянием тревожности. От общего числа респондентов, таковые составляют 32,5\%. 15,4\% из которых - исследуемые военнослужащие, относящиеся к нейтральному типу отношения к службе в армии, 84,6\% - к отрицательному.

Из общего числа исследуемых солдат срочной службы средний уровень ситуативной тревожности выявлен у $65 \%$ испытуемых. Если принять полученный результат за 100\%, то распределение по выделенным типам будет выглядеть следующим образом: 26,9\% - испытуемые, относящихся к службе в армии положительно, 42,3\% - нейтрально относящиеся к службе в армии, 30,8\% - военнослужащие с отрицательным типом отношения к военной 
службе. Низкий уровень ситуативной тревожности выявлен у 20\% исследуемых, из которых: 37,5\% - испытуемые с положительным типом отношения к службе в армии и 62,5\% - с нейтральным типом отношения к службе. Высокий уровень ситуативной тревожности наблюдается у $15 \%$ солдат срочной службы. Испытуемые с положительным и отрицательным типами отношения к службе в армии занимают здесь по 50\%.

Для определения доминирующего мотива у солдат срочной службы использовали методику А. Мехрабиана «Опросник измерения мотивации успеха».

Из полученных результатов видно, что у испытуемых преобладает мотив избегания неудач. В процентном соотношении, это выглядит следующим образом: мотив избегания неудач выявлен у 87,5\% исследуемых и 12,5\% более свойственен мотив стремления к успеху.

Исходя из этих данных можно сделать вывод о том, что только у 12,5\% исследуемых военнослужащих по призыву, выражена потребность в преодолении препятствий, у 87,5\% же преобладает мотив избегания неудач. Люди с подобным ведущим мотивом стремятся любым способом избежать наказания, они склонны к поиску помощи в достижении своих целей, как правило ставят либо очень легкие цели, либо заведомо недостижимые, не выполнение которых никак не повлияет на их самооценку.

Распределение результатов по выделенным подтипам выглядит следующим образом. У 25\% испытуемых с положительным типом отношения к службе в армии доминирует мотив стремления к успеху, у оставшихся же $75 \%$ - мотив избегания неудач. Результаты, относящиеся к испытуемым, занимающим нейтральную позицию по отношению к службе в армии, разделились так: 15,8\% мотив стремления к успеху, 84,2\% - мотив избегания неудач. И у $100 \%$ испытуемых, отрицательно относящихся к службе в армии, доминирует мотив избегания неудач.

Используя методику диагностики межличностных отношений Т. Лири, были выявлены следующие типы межличностных отношений (смешанные типы не выявлены): авторитарный - 20\%, эгоистический - 0 \%, дружелюбный - 40\%, альтруистический - 5\%, подчиняемый - 15\%, зависимый - 5\%, агрессивный - 3,33\%, подозрительный - 5\%.

Преобладающим типом межличностных отношений является фактор «Подчинение» - 65\% респондентов. Такие испытуемые характеризуется отказом от ответственности и позиции лидерства.

у наименьшего количества испытуемых выявлен фактор «Дружелюбие» - 35\% испытуемых. Испытуемые, имеющие высокую оценку по данному показателю, являются личностями, которые стремятся к дружелюбным отношениям.

Адекватно оценивают сложившиеся межличностные отношения $40 \%$ респондентов, $15 \%$ из которых - испытуемые, относящиеся к отрицательному типу отношения к службе в армии, 55\% - испытуемые с положительным типом отношения к службе и 30 \% респондентов, занимающих нейтральную позицию по отношению к службе в армии. Большая часть испытуемых в исследуемой группе имеют неадекватную самооценку - $60 \%$ от общего числа испытуемых. Распределение по типам будет выглядеть следующим образом: 74\% - военнослужащие по призыву с отрицательным типом отношения к службе в армии, 15\% - испытуемые нейтральным типом отношения к службе и $11 \%$ - респонденты, положительно относящиеся, к службе в армии.

Используя 16-РН опросник Р.Д. Кэттела (105 вопросов) имеем профили значений. Полученные данные по 16-РН опроснику Кэттела в группах военнослужащих с различным типом отношения к службе в армии проходили обработку. Наблюдалась следующая выраженность факторов у выделенных подтипов.

у испытуемых с положительным типом отношения к службе в армии более выраженными оказались следующие факторы: Н+ - данный фактор отвечает за следующие характеристики: смелость, предприимчивость, общительность, активность, импульсивность - 50\% испытуемых. С+ - эмоциональная устойчивость, выдержанность, трезво смотрит на вещи, реально оценивает обстановку, избегает трудности- 72\% испытуемых. У испытуемых с нейтральным типом отношения к службе в армии более выраженными оказались следующие факторы: С - отрицательный результат по данному фактору может свидетельствовать о таких характеристиках личности: критичность, объективность, жестокость - 65\%, занимающих нейтральную позицию по отношению к службе в армии. $\mathrm{G}+$ совестливость, точность, деловая направленность - 80\% испытуемых, отрицательно относящихся к службе в армии. I+ - Высокая оценка по фактору является показателем мягкости, чувствительности, утонченности, мечтательности, быстрая обучаемость; рассудительность, практичность, реалистичность.

Можно сделать вывод, что существуют различия в психологических особенностях.

Для измерения оценки значимости исследования использовали коэффициент корреляции Спирмена. Получили, что существует прямая связь между уровнями тревожности, самооценки, интеллектом, мотивацией.

Представленные обобщенные портреты солдат сроч- 
ной службы, разделенные по трем выделенным типам: с положительным, нейтральным и отрицательным типом отношения к службе в армии помогли выбрать направление профилактической работы.

Испытуемые, в зависимости от принадлежности их к тому или иному подтипу, отличаются друг от друга по характеристикам эмоциональной, коммуникативной, интеллектуальной морально-нравственной и волевой сфер, так же по уровню самооценки и личностной тревожности. На основе полученных в результате проведенного исследования данных были составлены рекомендации.
Необходим благоприятный социально-психологический климат в воинском коллективе, которого можно добиться постепенной гармонизацией отношений. Необходима постоянная качественная психологическая диагностика возможных нарушений нормального функционирования психических процессов военнослужащих, и своевременное принятие мер по их устранению. Данное исследование может помочь психологам и социальным работникам создать социально-психологические условия, способствующие снижению уровня негативного восприятия молодыми людьми призывного возраста службы в армии.

\section{ЛИТЕРАТУРА}

1. Л Лепешинский И.Ю.; Основы военной педагогики и психологии: конспект лекций // Ю.И. Лепешинский и др.; Омск: Изд-во ОмГТУ, 2011. - 179с.

2. Леонтьев А.А. Лекции по общей психологии: Учеб. пособие для студентов вузов, обучающихся по специальности «Психология» // А.Н. Леонтьев, Москва.: Смысл, 2011- 509 с.

3. Маклаков А.Г. Общая психология. Учеб. пособие для студентов вузов и слушателей курсов психол. дисциплин Москва.: Наука, 2009. - 582 с.

4. Немов Р.С. Социальная психология: история, предмет и методы: общение и межличностные отношения: социальные группы: массовидные явления психики: социальная психология и практика] / Р.С. Немов, И. Р. Алтунина; Санкт-Петербург.: Питер, 2008. - 427с.

5. Реан А.А.; Молодежь и социум: психологические и педагогические проблемы: сборник статей / М-во внутренних дел Российской Федерации, Московский ун-т; под ред. А.А. Реана. Москва.: Смысл, 2009 - 123 с.

6. Шапошников М.С. Психологические особенности исполнительской деятельности военнослужащих, проходящих службу по призыву: автореферат дис. ... кандидата психологических наук: Шапошников Максим Сергеевич; Москва.: Лабиринт, 2009. - 25 с.

(c) Фёдоров Александр Фёдорович (zimbur79@mail.ru).

Журнал «Современная наука: актуальные проблемы теории и практики»

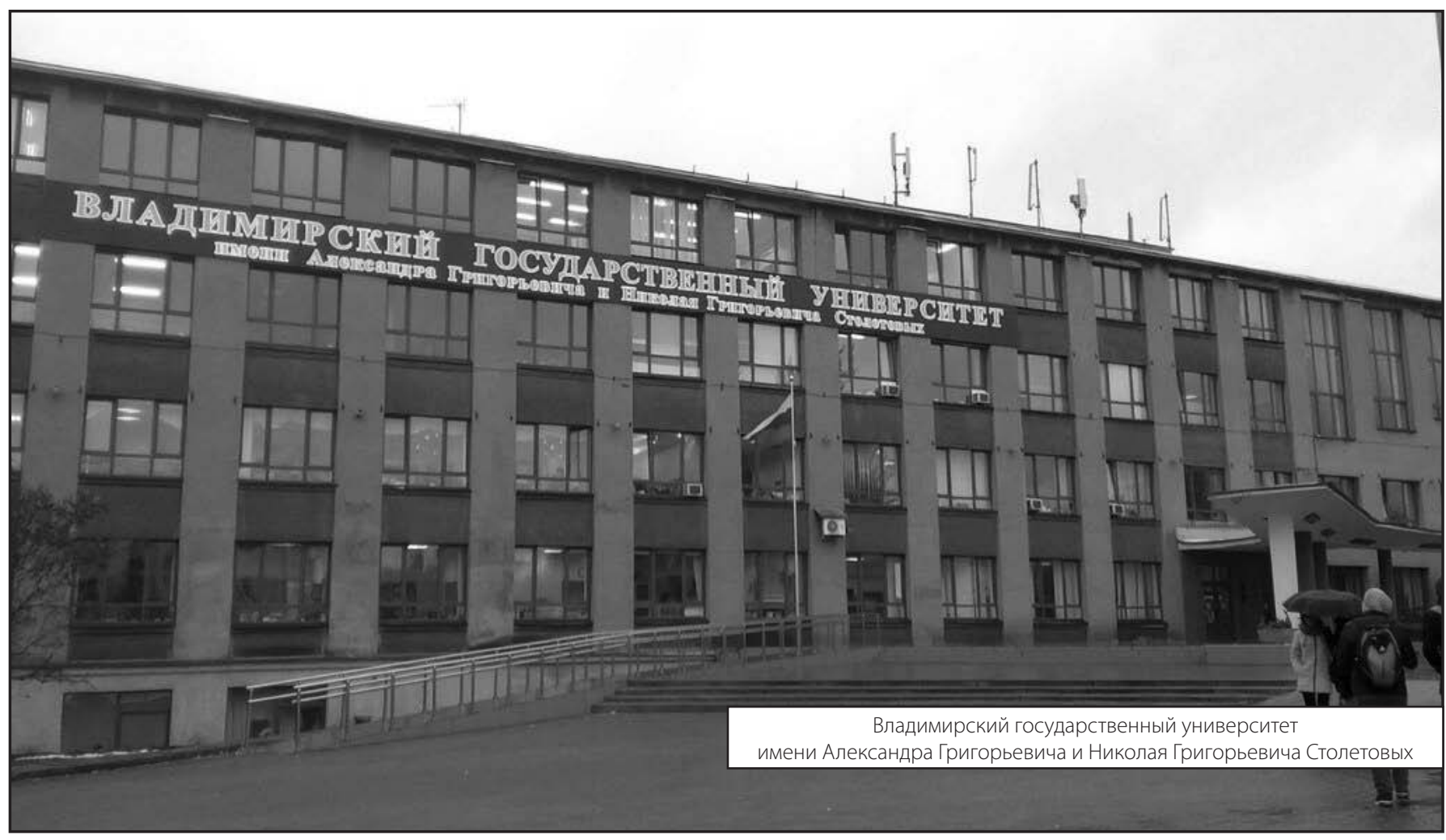

